\title{
A Comparative Study on New Media Marketing in Domestic and Foreign Public Libraries
}

\author{
Yan Xu \\ Library of Beihua University, NO.15, Jilin Road, Jilin City, Jilin Province, China \\ Emai1:494660880@qq.com
}

\begin{abstract}
Currently, new media has become the popular platform for brand marketing and services promoting of public libraries. Using the method of online survey, literature analysis and comparative analysis, this paper chooses 4 foreign public libraries and 4 domestic public libraries as the research samples and compares the differences in new media marketing between them from new media marketing tools, marketing content and marketing strategies, then makes some proposals and measures to perfect domestic public libraries' new media marketing, so as to provide references to improve the libraries' social awareness and benefits.
\end{abstract}

Keywords. Public libraries, new media marketing, comparative analysis, library marketing.

\section{Introduction}

With the rapid development of Internet technology, new media, such as smart phones, tablet PCs, social networks, digital TV and so on, has become the main platform for users to obtain and share information. According to eMarketer data show that in 2016 the Chinese Internet media access time for the first time than the traditional media, accounting for $50.6 \%$ of the daily media time [1]. The new media with its massive user base, rapid information exchange and other characteristics, as each industry marketing and product promotion of the best channel, but also opens up a new way for public libraries to increase social awareness and the promotion of information and knowledge service.

At present, the new media marketing related research has become the focus of attention of scholars at home and abroad. Foreign scholars E.Vassila analyzes the role of Twitter as a new social media, in promoting library service marketing and improving the user's attention [2]. D.S.Negi and other research on how to use mobile devices for library readers to provide more convenient information services [3]. The domestic scholar Zhang Ling takes 13 libraries as an example, analyzes the problems existing in the promotion of resources and services, and puts forward the strategy of promoting the application of the library with the new media technology [4]. From the existing research results, most of the new media in the library service promotion and brand marketing in the application mode and strategy. However, the comparative study of new media marketing for public libraries at home and abroad is relatively small. Therefore, this paper selects several public libraries at home and abroad as an example, from the new media marketing tool type, the main contents and strategies to compare the differences between them, so as to provide reference for the development of China's library.

\section{New media marketing of public library}




\subsection{New media and new media marketing}

The new media is a new media form with respect to traditional media, domestic and foreign scholars generally believe that the new media is based on network technology, mobile communication technology, digital technology, relying on the computer, intelligent mobile phone, digital TV and other terminal equipment, to achieve information exchange and sharing between users of media forms, including portals, search engines, social media the application of digital TV, mobile, etc.. New media marketing, just as its name implies, is the use of new media platforms to carry out marketing activities. Baidu encyclopedia is defined as: the realization of enterprise soft penetration business strategy in the new form of media, so that consumers recognize some concepts, ideas and analysis of ideas by means of the media usually expression and dissemination of public opinion, so as to achieve the enterprise brand promotion, product sales to [5]. At present, the mainstream of the new media marketing methods for WeChat, micro-blog, client marketing, foreign mainly for social media, online video marketing.

\subsection{The significance of Public Libraries in developing new media marketing.}

The concept of library marketing first appeared in 1990s, is to enhance the library brand image, promotion of information service and to gain public recognition, so as to maximize the social benefits as the fundamental purpose, to carry out a series of targeted activities for existing and potential users. At present, with the emergence of all kinds of new media, people tend to get more intuitive and convenient digital resources and network information. The function and status of the public library are threatened, and the service promotion and brand publicity should be strengthened while strengthening the digital and mobile information services. New media has brought new opportunities for the public library marketing. First, the new media users group public opinion advantage helps public library awareness; second, the public library can make full use of new media dissemination speed, the variety of the content features to improve the efficiency and quality of information service; thirdly, the characteristics of new media can strengthen the interaction between the public library and user communication, so as to provide accurate personalized service.

\section{Domestic and foreign public library new media marketing comparative analysis.}

\subsection{Sample selection and research methods}

The main content of the public library marketing is nothing more than two points: brand marketing and service marketing, and foreign public library service marketing in the subdivision level is more abundant. First of all, in terms of brand marketing, foreign public libraries flexible use of social media and other types of websites to attract the attention of the majority of users. For example, many public libraries will use Pinterest and YouTube pictures, video sharing websites brochures and video; the New York public library by Twitter and user real-time communication, the topic of organization and a variety of interactive games, increase site traffic. Secondly, in the service marketing, including the news announcement, theme activities; library resources, academic literature, video and other resources promotion services; training courses, online education, business counseling and other public service. For example, the Australian National Library by Facebook post pictures, video or news release important news, activities in the form of links to resources, release all kinds of theme speech or report by the official podcast website provides online library [6]; digital resources or scientific literature to readers; Boston Public Library through Linkedin website cooperation, provide employment guidance for users. In addition, the foreign public library has also carried out the payment of the project marketing, such as the British National Library Home page to the user sales of literary and artistic exhibition tickets.

\subsection{The new media marketing of Public Library}

The main content of the new media marketing of domestic public library also involves the brand marketing and service marketing. In the aspect of brand marketing is mainly embodied in the creation of library image and brand culture, for 
example, the Hangzhou library "Wenlan lecture series of culture, integration of resources to WeChat, mobile client, digital TV and other new media platform, users can free access to the Hangzhou area, has greatly enhanced the scope of the audience[7]. The library of Hangzhou library social media the current marketing situation and Strategy Research -take" Wenlan auditorium "as an example; Shanghai library with the Oriental TV TV platform to carry out, urban culture, access to a wide range of social benefits. In the new media service marketing, the domestic library is usually in WeChat, micro-blog, the mobile client provides event announcements push, readers information query service, reference service, exquisite articles and books and other information to the library service promotion. For example, the Shenzhen port mobile phone clients to integrate the digital literature resources of Shenzhen library, Shenzhen University city library, provides a great convenience for the readers to obtain literature resources[8]; Hangzhou Library in the "offline" lectures, art exhibitions, micro theater and other special activities, and online publicity and reports by WeChat national public number; the WeChat platform not only push the fragmentation of exquisite articles, announcements, also provides a classic audio-visual and poetry reading service.

\subsubsection{Comparative analysis of new media marketing tools}

The main platform tools of the new media marketing of the new media of the four sample libraries in foreign countries are shown in table one.

Table 1. New media marketing tool of Public Library in foreign countries.

\begin{tabular}{|l|l|l|}
\hline Library name & New media marketing tools & $\begin{array}{l}\text { Features new media } \\
\text { marketing tools }\end{array}$ \\
\hline $\begin{array}{l}\text { New York Public } \\
\text { Library }\end{array}$ & $\begin{array}{l}\text { Facebook, Twitter, YouTube, Blog, podcast, } \\
\text { Google+, NYPL Mobile (Mobile Library), Official } \\
\text { website, etc. }\end{array}$ & $\begin{array}{l}\text { Facebook, Twitteretc. } \\
\text { Social media }\end{array}$ \\
\hline $\begin{array}{l}\text { Burlington Public } \\
\text { Library }\end{array}$ & $\begin{array}{l}\text { BPL Mobile (Mobile Library),Facebook, YouTube, } \\
\text { Official website }\end{array}$ & $\begin{array}{l}\text { BPL Mobile Mobile } \\
\text { Library })\end{array}$ \\
\hline $\begin{array}{l}\text { National Library of } \\
\text { the United Kingdom }\end{array}$ & $\begin{array}{l}\text { Tripadvisor, Facebook, twitter, YouTube, } \\
\text { Google+, pinterest, Official website }\end{array}$ & Tripadvisor platform \\
\hline $\begin{array}{l}\text { Australian National } \\
\text { Library }\end{array}$ & $\begin{array}{l}\text { Twitter, Facebook, Youtube, Blog, Flickr, Sound } \\
\text { Cloud, Podcasts, Official website }\end{array}$ & $\begin{array}{l}\text { Social media, video } \\
\text { sites }\end{array}$ \\
\hline $\begin{array}{l}\text { Boston Public } \\
\text { Library }\end{array}$ & $\begin{array}{l}\text { Twitter, Facebook, linkedin, Flickr, Pinterest, } \\
\text { YouTube, Instagram, Boston Public Library } \\
\text { Community Social Media page }\end{array}$ & $\begin{array}{l}\text { Boston Public } \\
\text { Library Community } \\
\text { Social Media page }\end{array}$ \\
\hline
\end{tabular}

Can be seen from the table, often use foreign public library marketing new media tools with social networking, video sharing websites, digital broadcasting, photo sharing website, micro blog, mobile client, the official website of the digital library etc.. Among them, Facebook, Twitter and Google+ belong to social media, their huge user group, interactivity and immediacy, become the mainstream channels of library marketing; Pinterest, Flickr for image share of new media, the library can show the style, activity or celebrity pictures through such platforms; Youtube, Viemo is a video sharing site playing videos, activities or lecture video provides the best way to public library; SoundCloud and Podcasts in the form of digital radio podcast website provides new channel for reports, news stories push library. In addition, foreign public libraries will be through cooperation with other industry website publicity, such as the British National Library and Tripadvisor (tourism website) to establish links. Visible, foreign public library marketing a large number of new media tools, a wide range of media content presented in the form of diversification, both text class, as well as pictures, audio and video.

\subsubsection{The main tools of new media marketing in the domestic public libraries}


Table 2. New media marketing tool of Public Library in China.

\begin{tabular}{|c|l|l|}
\hline Library name & New media marketing tools & $\begin{array}{l}\text { Major new media } \\
\text { marketing tools }\end{array}$ \\
\hline Shanghai library & $\begin{array}{l}\text { WAP portal, mobile client APP, WeChat, micro-blog, } \\
\text { digital TV, digital library official website }\end{array}$ & $\begin{array}{l}\text { Micro-blog } \\
\text { marketing (pictured } \\
\text { above) }\end{array}$ \\
\hline $\begin{array}{c}\text { National Library } \\
\text { of China }\end{array}$ & $\begin{array}{l}\text { Digital library official website, micro-blog, WeChat, } \\
\text { RSS subscription, SMS, mobile client (Palm figure } \\
\text { APP) }\end{array}$ & $\begin{array}{l}\text { WeChat, mobile } \\
\text { library }\end{array}$ \\
\hline Shenzhen Library & $\begin{array}{l}\text { Digital Library's official website, news network, } \\
\text { WeChat, micro-blog, mobile phone client }\end{array}$ & $\begin{array}{l}\text { WeChat, news } \\
\text { network }\end{array}$ \\
\hline Hangzhou Library & $\begin{array}{l}\text { Digital library official website, digital TV, WeChat, } \\
\text { micro-blog, mobile phone client }\end{array}$ & $\begin{array}{l}\text { Micro-blog, mobile } \\
\text { client }\end{array}$ \\
\hline
\end{tabular}

Can be seen from the table, the main domestic new media marketing of public library with the use of mobile phone library, mobile client application (APP), WeChat and micro-blog and other social media, digital library, digital TV website. Among them, the public library and public official WeChat micro-blog account is currently the most popular marketing platform, can be used to release the news, recommended reading, event notifications, and interact with the reader to provide reference service; SMS and WAP portal is the earlier emergence of new media platform, through information for the users to send notifications the book to the library, the basic message book, has been rarely used; mobile client application can satisfy the user access to library consultation, whenever and wherever possible bibliographic retrieval and reading needs, public libraries often open up special plate in the client, building brand display activities; fusion with digital TV, very well with the television media this propaganda the channel, expand the scope of the audience. From the whole, the new media marketing channels of China's public libraries gradually widened, social media and digital media utilization increased.

\subsection{Comparative analysis of new media marketing content}

\subsubsection{The main contents of new media marketing in foreign public libraries}

The main content of the public library marketing is nothing more than two points: brand marketing and service marketing, and foreign public library service marketing in the subdivision level is more abundant. First of all, in terms of brand marketing, foreign public libraries flexible use of social media and other types of websites to attract the attention of the majority of users. For example, many public libraries will use Pinterest and YouTube pictures, video sharing websites brochures and video; the New York public library by Twitter and user real-time communication, the topic of organization and a variety of interactive games, increase site traffic. Secondly, in the service marketing, including the news announcement, theme activities; library resources, academic literature, video and other resources promotion services; training courses, online education, business counseling and other public service. For example, the Australian National Library by Facebook post pictures, video or news release important news, activities in the form of links to resources, release all kinds of theme speech or report by the podcast; library official website to provide online digital resources or scientific literature to readers; through Boston Public Library and Linkedin site cooperation, provide employment guidance for users. In addition, the foreign public library has also carried out the payment of the project marketing, such as the British National Library Home page to the user sales of literary and artistic exhibition tickets.

\subsubsection{The main contents of the new media marketing in the domestic public libraries}

The main content of the new media marketing of domestic public library also involves the brand marketing and service marketing. In the aspect of brand marketing is mainly embodied in the creation of library image and brand culture, for 
example, the Hangzhou library "Wenlan lecture series of culture, integration of resources to WeChat, mobile client, digital TV and other new media platforms, Hangzhou area users can free access to the library, greatly enhanced the scope of the audience by Shanghai library; Oriental TV, TV platform to carry out urban culture, access to a wide range of social benefits. In the new media service marketing, the domestic library is usually in WeChat, micro-blog, the mobile client provides event announcements push, readers information query service, reference service, exquisite articles and books and other information to the library service promotion. For example, the Shenzhen port mobile phone clients to integrate the digital literature resources of Shenzhen library, Shenzhen University city library, provides a great convenience for the readers to obtain literature resources; Hangzhou Library in the "line" art exhibitions, lectures, and other characteristics of the micro theatre activities, and online publicity and reports by WeChat public No.; the National Library of WeChat platform not only push the fragmentation of exquisite articles, Activities Notice also provides a classic audio-visual and poetry reading service.

\subsection{Comparative analysis of new media marketing strategy}

\subsubsection{New media marketing strategy of Foreign Public Libraries}

New media marketing strategies of foreign public libraries are abundant, mainly including mobile marketing, celebrity marketing, marketing to the game, users participate in the construction of marketing. Among them, the activities of marketing is to take action as the carrier, to guide readers to participate in interactive, enhance the user experience at the same time pass the brand value. For example, make full use of micro Facebook and Twitter activities of Australian public libraries, users carry out self sent push, photo sharing, knowledge competition and diversified activities, arouse their enthusiasm, thereby increasing the library visits. Taking advantage of marketing is the use of celebrity fans effects of celebrity, invite them to offer lectures, interviews, or invite shooting star library theme pictorial, video or photo sharing to social networking sites, to attract the attention of fans. Game marketing is loved by the majority of users, with entertainment driven propaganda. Such as the New York public library development of library online interactive fun games, game winners can enjoy activities such as library tickets, discount stores and other privileges [9]. User participation in the construction of marketing is to allow users to participate in the construction of library resources, strengthen the user experience. For example, the library's collection of Boston Public Library is connected with social media, allowing users to tag, comment, and share a list of books [10].

\subsubsection{New media marketing strategy of domestic public libraries}

Domestic public libraries are constantly absorbing foreign experience, enrich the new media marketing strategy. At present, there are mainly activities interactive marketing, hot events or topic marketing, micro film marketing, etc.. Among them, the activities of marketing and foreign marketing is similar, interesting activities will enhance the user experience. For example, micro-blog, WeChat and other Shanghai library to carry out knowledge quiz, book prize, recommended online entertainment exhibition activities, and readers one-on-one interaction, providing personalized service precision. Hot event or topic marketing is the public library planning, the use of social influence of the popular events or topic of public opinion, to attract public attention, to achieve the purpose of publicity. Hangzhou library, for example, has become a hot topic for micro-blog, becoming a hot topic in the world. It has been named "the warmest Library in history". It has successfully promoted the idea of library service [11]. Micro film marketing is a relatively new mode, the real story about through the lens of the library, library culture and publicity services, to attract readers to pay more attention to and accept the library service. For example, the national library has held a "library story readily shoot" creative video contest "met the most beautiful you", released to all kinds of new media platform for promotion [12].

\section{Domestic and foreign public library new media marketing differences and enlightenment}




\subsection{New media marketing differences between domestic and foreign public libraries}

By comparing the new media marketing of the domestic and foreign public library analysis, found that the differences are the following: first of all, from the point of view of marketing tools, the use of foreign public libraries of new media types, a large number of social networking sites, including pictures and video websites, digital broadcast platform, mobile phone client, job sites, travel sites etc.. The new media marketing tool of domestic public library mainly include social media, mobile phone APP, library's official website, digital tv. Although the number and type of growth trend, but compared to foreign countries are still less, but also in the content of the more text, pictures, audio, video based platform for less. Secondly, from the marketing point of view, the contents of service marketing in foreign public libraries more abundant, includes not only the basic reading service, information resources, activities and push notifications, skills training, employment guidance and other public services. In contrast, the domestic public library service marketing is mainly the basic information resources push, news and activities, and so on, the more scarce. Finally, from the point of view of marketing strategy, the domestic and foreign public libraries have different characteristics. Foreign attention to the user experience, such as through the game, the user to participate in the construction of resources and other forms to attract their attention, and can work with the field of cooperation to broaden the channels of brand promotion. Domestic is good at using the power of public opinion to achieve the effect of publicity, with interesting things to promote, but compared to foreign countries, new media marketing channels and strategies are still to be widened.

\subsection{The enlightenment to the new media marketing of Public Library in China}

In this paper, through the comparative analysis of new media marketing of the domestic and foreign public library, summed up the differences, and learn from foreign advanced marketing mode, brings the following enlightenment to our public library: a new media marketing culture building full participation, strengthening the librarian's new media skills, to mobilize the enthusiasm of all staff participation service promotion. Two, open and comprehensive utilization of various new media marketing platform, not limited to the mobile phone client, portals, social media, and can also strengthen the tourism website, job site, watercress reviews website cooperation, broaden the scope of marketing. Three, to explore new media marketing content rich, expand service areas, not only to meet the basic public access to information, knowledge of the demand, but also for user education, employment, entrepreneurship, leisure to provide reference and guidance, for example, to carry out online training courses, push occupation information, entrepreneurial knowledge etc.. Four, combined with a variety of marketing strategies, should actively absorb foreign game marketing, user participation marketing, celebrity marketing, combined with excellent domestic marketing mode, according to different marketing object, platform and content users loved the way. Five, pay attention to the user experience, to attract users to participate, give full play to the function of the user from the media to build the library resources and services online, to mobilize the enthusiasm of the user, and through their interaction in social circles, the "viral marketing" strategy, promotion of Library brand.

\section{The conclusion}

This paper selected foreign New York public library, the Australian National Library, the British Library, Boston Public Library, and Shanghai library, Shenzhen library, Hangzhou National Library and the National Library as a sample, using the network investigation, document analysis, comparative analysis methods from the new media marketing tools, content and strategy of the three aspects of comparative analysis at home and abroad the public library and the similarities and differences of new media marketing. At last, according to the current situation of domestic public library's new media utilization, the corresponding countermeasures and suggestions are put forward. The research of this paper has a certain positive significance to broaden the new media marketing channels, innovative brand marketing strategy and service marketing content, and improve the social awareness and social benefits of the library. But this research also has certain limitation, for example, the sample size is less, and the universality is not guaranteed. The future research will expand the sample scope, and further discuss the new media marketing mode of domestic and foreign public library. 


\section{References}

1. eMarketer. 2016 Chinese Internet media access time for the first time more than traditional media:[2016-07-20]. Vassilakaki E, Garoufallou E.The impact of Twitter on libraries: a critical review of the literature. The electronic library, 2015,33(4):795 - 809.

2. Vassilakaki E, Garoufallou E.The impact of Twitter on libraries: a critical review of the literature. The electronic library, 2015,33(4):795 - 809 .

3. Negi D S.Using mobile technologies in libraries and information centers. Library hi tech news, 2014, 31(5):14-16.

4. Zhang Ling. Library publicity and promotion strategy under the new media technology environment. Library and information science, 2015,59 (01): 78-81.

5. Baidu encyclopedia. New media marketing.[2016-07-20].http://dwz.cn/3SKksk.

6. Lu Zhenbo, Li Xiaodong, Cheng Yanxia. A case study on social media marketing of foreign libraries and Its Enlightenment. Journal of university library, 2014 (04): 76-82.

7. Li Huihui, Sun Yanxiang. The Hangzhou library social media marketing present situation and Strategy Research -take "Wenlan auditorium" as an example of. Communication of science and technology, 2015 (21): 20-21+34.

8. Ma new media service. library and information service of public library, 2014, 58 (6): 70-74.

9. Li Jinbo. New York public library social media marketing practice. Library forum, 2016 (04): 120-125.

10. Yin Yuehuan. Public Library of. media marketing method, Northeast Normal University, 2014

11. Yang Mei. Hangzhou micro-blog Promotion Strategy Research Library. Library forum, 2012,32 (05): $157-160$.

12. Zuo Bin Ningbo. Social media library marketing strategy under the situation of the implementation of. Library research, 2015 (16): 16-20.16-20. 